\title{
Spatial models for selecting the most suitable areas of rice cultivation in the Inland Valley Wetlands of Ghana using remote sensing and geographic information systems
}

\author{
Muralikrishna Gumma, ${ }^{\text {a }}$ Prasad S. Thenkabail, ${ }^{\mathrm{b}}$ Hideto Fujii, ${ }^{\mathrm{c}}$ and \\ Regassa Namara ${ }^{\mathrm{c}}$ \\ ${ }^{a}$ Remote Sensing and Geographic Information Systems, International Water Management \\ Institute (IWMI), ICRISAT Campus, Patancheru, Hyderabad, India \\ m.gumma@cgiar.org \\ ${ }^{\mathrm{b}}$ Southwest Geographic Science Center, U.S. Geological Survey (USGS), Flagstaff, Arizona \\ 86001 \\ pthenkabail@usgs.gov \\ 'International Water Management Institute (IWMI), Ghana Office, Accra, Ghana CT 112 \\ h.fujii@,cgiar.org; r.namara@ccgiar.org
}

\begin{abstract}
The overarching goal of this research was to develop spatial models and demonstrate their use in selecting the most suitable areas for the inland valley (IV) wetland rice cultivation. The process involved comprehensive sets of methods and protocols involving: (1) Identification and development of necessary spatial data layers; (2) Providing weightages to these spatial data layers based on expert knowledge, (3) Development of spatial models, and (4) Running spatial models for determining most suitable areas for rice cultivation. The study was conducted in Ghana. The model results, based on weightages to 16-22 spatial data layers, showed only 3-4 \% of the total IV wetland areas were "highly suitable" but $39-47 \%$ of the total IV wetland areas were "suitable" for rice cultivation. The outputs were verified using field-plot data which showed accuracy between 84.4 to $87.5 \%$ with errors of omissions and commissions less than $23 \%$. Given that only a small fraction $(<15 \%$ overall) of the total IV wetland areas (about $20-28 \%$ of total geographic area in Ghana) are currently utilized for agriculture and constitute very rich land-units in terms of soil depth, soil fertility, and water availability, these agroecosystems offer an excellent opportunity for a green and a blue revolution in Africa.
\end{abstract}

Key words: spatial model, inland valley wetlands, land suitability, most suitable areas selection, rice, agriculture, water, remote sensing, Ghana, Africa.

\section{INTRODUCTION}

Rice constitutes a significant component of major food staples and is of principal importance in West Africa. Records show a rapid increase of rice consumption in West Africa from 1 million tonnes in 1964 to 8.6 million tonnes in 2004 [1]. In Ghana the rice consumption increased from 7.4 kilogram per capita per annum between 1982 and 1985 [2] to $13.3 \mathrm{~kg}$ per capita per annum (Government of Ghana, 1996). National statistics on rice production and consumption in Ghana indicated that in 2005, a total of 142,000 tonnes of milled rice were domestically produced with 113,600 tonnes available for human consumption. Domestic food supply and demand status in Ghana in 2005 indicated milled rice deficit of 199,400 tonnes (Government of Ghana, 2006). Under these circumstances, attaining self-sufficiency of rice is a critical strategy for many countries in West Africa including Ghana. However, rice production in most sub-Saharan Africa (SSA) falls below consumption demand due to a variety of reasons that could be categorized as bio-physical, socio-economic, technological, 
and eco-environmental factors. Therefore, to resolve the deficiency in rice production there is a need to implement strategies for increasing productivity by expansion of production capacity.

Inland valley (IV) wetlands are highly suitable for rice cultivation in Ghana [3]. These IVs present great potential for agricultural expansion and intensification in West Africa to help feed the fast growing populations and changing food habits [3]. The IVs occur in the upper reaches of river systems in which river alluvial sedimentation processes are absent or imminent only. They are composed of valley bottoms, hydromorphic valley fringes, and minor floodplains, which may be submerged for part of the year. Throughout the West African region the estimated area of IVs range between $8-28 \%$ of the total geographic area with only about $7-20 \%$ of this area cultivated [4,5]. The IV wetland areas are highest in the humid forests, followed by derived savannas, southern Guinea Savanna, Northern Guinea Savanna, and Sudan Savanna, and Sahel.

However the importance of the IV wetlands actually increase in drier areas, since in these areas the importance of IVs for lowland rice and for cultivating other crops increase as well. The uplands in these regions have severe water scarcity for most of the year $[4,5]$. It is estimated that if an extra 2 million hectares of IV wetlands are used for rice cultivation, producing at an average yield of 3 tonnes per hectare, the West Africa region could halt the importation of rice from elsewhere. These IVs also present equally great potential for other crops such as vegetables, banana, and cassava [6-10]. However, similar to any other ecosystems, these IVs show a great diversity in their physical, bio-physical, and hydrological characteristics [11]. If these IV wetland ecosystems are evaluated in terms of their biophysical, technological, socio-economic, and eco-environmental factors, they will collectively determine their suitability for cultivation. Such an outcome will enable farmers and the policy makers to identify the most suitable areas that could be developed promoting sustainable farming systems. In performing land suitability analyses remote sensing and geographic information systems (GIS) data and tools and techniques provide a good platform for data generation, integration, processing, and analyses.

Given the above background, the main objective of this project was to evaluate and map suitable IVs for paddy cultivation based on developed indicators categorized as bio-physical factors, socio-economic factors, and eco-environmental factors. The specific objectives of the GIS-RS spatial analysis component of the project were to: (1) Identify critical spatial data layers needed for the land suitability model for inland valley rice cultivation; (2) Provide weightages to spatial data layers and for classes within each spatial data layer based on expert knowledge; (3) Develop spatial model that will provide answers to relevant questions and identify most suitable areas for rice cultivation IV wetlands based on the spatial data layers and their weightages.

\section{STUDY AREA}

The spatial model for selecting the most suitable areas for inland valley (IV) wetland cultivation will be illustrated for 2 key study areas in Ghana. These are (Fig. 1): (a) Tamale in Northern Ghana, and (b) Kumasi in Southwestern Ghana. Tamale falls in Guinea savanna zone. The annual rainfall of the study watersheds is around $1100 \mathrm{~mm}$ on an average. In contrast, Kumasi falls on semi-deciduous forest zone. The annual rainfall of the study watersheds is around $1400 \mathrm{~mm}$ on an average. In both study areas, an area covering $100 \mathrm{~km} \mathrm{X}$ $100 \mathrm{~km}$ was selected for semi-detailed characterization using Landsat $(30 \mathrm{~m})$ resolution and a area of $15 \mathrm{~km} \mathrm{X} 15 \mathrm{~km}$, within the semi-detailed area, was selected for detailed characterization using sub-meter to $4 \mathrm{~m}$ quickbird and $\backslash$ or IKONOS imagery. 

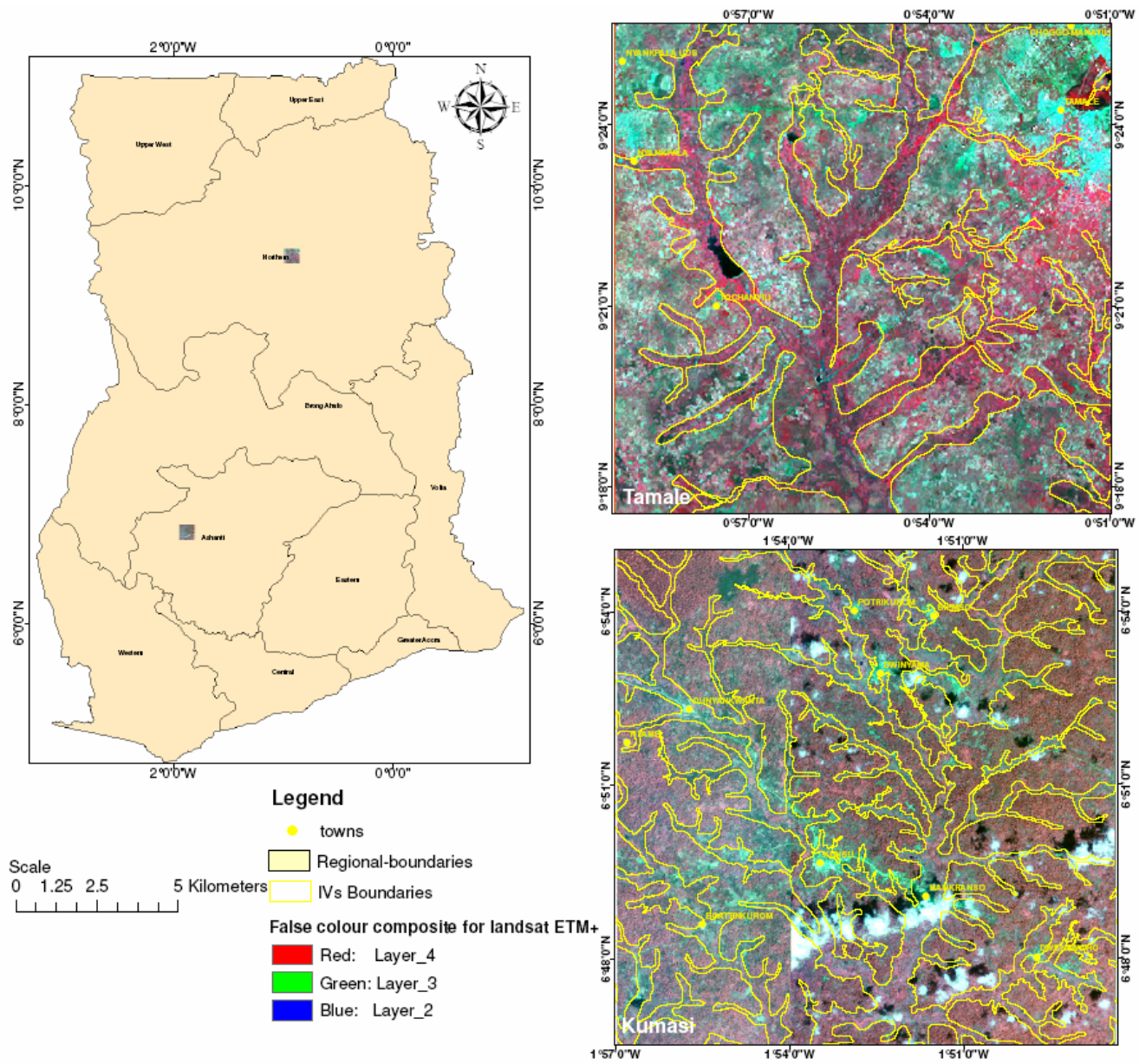

Fig. 1. Study areas in Ghana: (a) Tamale in North (shown using IKONOS imagery), (b) Kumasi in Southwest (shown using Landsat imagery). The yellow lines indicate the delineation of IV wetland bottomlands.

\section{METHODOLOGY}

The methodology (Fig. 2) for determining the most suitable areas for rice cultivation in the IV wetlands consisted of 4 specific modules: (1) Identification and development of necessary spatial data layers; (2) Providing weightages to these spatial data layers, and (3) Development of spatial model, and (4) running those models for determining most suitable areas for rice cultivation. 


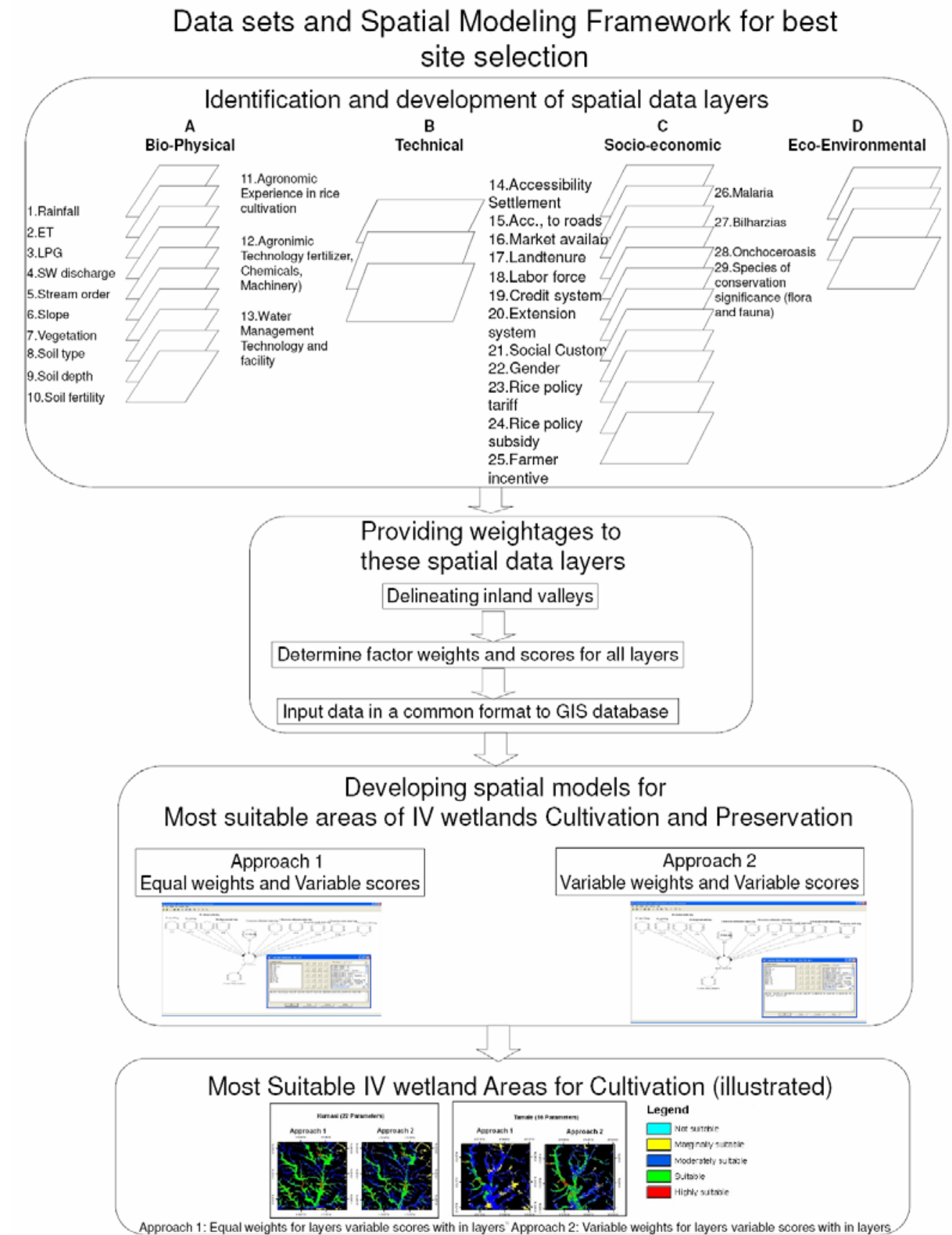

Fig. 2. Spatial model steps involved in selecting the most suitable areas for rice cultivation in IV wetlands.

\subsection{Identification of spatial data layers}

A total of 29 key spatial data layers (Fig. 2) were identified as ideal for establishing most suitable areas for rice cultivation. The variables considered were based on their importance for IV wetland rice cultivation. These spatial data layers were categorized into following broad groups: 


\subsubsection{Biophysical, Climatic, and Water Variables:}

The biophysical, climatic, and water variables considered were Rainfall, evapotranspiration (ET), length of growing period (LGP), surface water discharge, stream order, slope, vegetation, soil type, soil depth, and soil fertility.

\subsubsection{Technical factors}

The technical factors were agronomic experience, agriculture technology, and water management.

\subsubsection{Socio-economic factors}

The socio-economic factors were accessibility settlements, road-networks, markets, land tenure, labor force, credit systems, extension system, social customs, gender, rice policy tariff, rice policy subsidy, and farmers incentive.

\subsubsection{Eco-environmental factors}

The eco-environmental factors were malaria, bilhazias, onchocercasis species, and conservation of significant flora and fauna.

However, data was available for 22 variables for Kumasi and 16 variables in Tamale (these will be discussed later; see Table 6 for example).

\subsection{Preparation of spatial data layers}

Some of the layer information's were gathered from satellite images, field surveys, and other global datasets. Slope, stream order, road network, markets, settlements, and land use lland cover (LULC) analyzed directly from satellite data. Rainfall, ET, LGP, and diseases data were extracted from other studies [12]. Other socioeconomic factors and soil parameters from field surveys using GPS and processed in GIS by inverse distance weighted technique (IDW) (Arc GIS 9.2).

\subsubsection{Satellite sensor data}

Landsat ETM+ tiles were downloaded from the University of Maryland, global land cover facility website (http://glcf.umicas.umd.edu/index.shtml). The IKONOS data were purchased through Landsat Science Team allocations. The characteristics of these images are shown in Table 1. All these images were converted into at-sensor reflectance based on the equations and algorithms presented in $[10,11$, and 12]. The Landsat ETM+ and IKONOS data (Table 1) were used as the primary data sources for spatial parameters like settlements, markets, roads, land uselland cover (LULC), and vegetation.

\subsubsection{Normalization}

The IKONOS, and ETM+ sensors have different radiometric resolutions, hence their respective digital numbers (DNs) carry different levels of information and cannot be directly compared. Therefore, they were converted to absolute units of radiance $\left(\mathrm{W} \mathrm{m}^{-2} \mathrm{sr}^{-1} \mu \mathrm{m}^{-1}\right)$, then to apparent at-satellite reflectance (\%), and finally to surface reflectance (\%) after 
atmospheric correction. Details on these conversions are provided due to the uniqueness of the sensors involved.

Table 1. Characteristics of satellite sensor data used in the study.

\begin{tabular}{|c|c|c|c|c|c|c|c|c|c|}
\hline Sensor & Spatial & Spectral & Radiometric & band range & Irradiance & Sun elevation & $\begin{array}{l}\text { Acquisition } \\
\text { of the }\end{array}$ & $\begin{array}{l}\text { Earth sun } \\
\text { distance }\end{array}$ & Data points \\
\hline & (meters) & $(\#)$ & (bit) & $(\mu \mathrm{m})$ & $\begin{array}{l}\left(\mathrm{W} \mathrm{m}^{-2} \mathrm{sr}^{-1} \mu \mathrm{m}^{-}\right. \\
\left.{ }^{1}\right)\end{array}$ & $\theta$ & imagery & $\mathrm{D}$ & $\begin{array}{l}\text { (\# per } \\
\text { hectares) }\end{array}$ \\
\hline \multirow[t]{8}{*}{ Landsat ETM+ } & 30 & 8 & 8 & $0.45-0.52$ & 1970 & 56.04 (for $\mathrm{p} 194 \mathrm{r} 54$ ) & 20-Mar-02 & 0.9911 & $44.4,11.1$ \\
\hline & & & & $0.53-0.61$ & 1843 & 58.61 (for $\mathrm{p} 194 \mathrm{r} 55$ ) & 7-Nov-99 & 0.9959 & \\
\hline & & & & $0.63-0.69$ & 1555 & & & & \\
\hline & & & & $0.75-0.90$ & 1047 & & & & \\
\hline & & & & $1.55-1.75$ & 227.1 & & & & \\
\hline & & & & 10.412 .5 & 0 & & & & \\
\hline & & & & $2.09-2.35$ & 1368 & & & & \\
\hline & & & & $0.52-0.90$ & 1352.71 & & & & \\
\hline \multirow[t]{4}{*}{ IKONOS } & $1-4$ & 4 & 11 & $0.445-0.516$ & 1930.9 & 68.23(Tamale) & 1-Oct-07 & 1.0005 & 10000,625 \\
\hline & & & & $0.506-0.595$ & 1854.8 & 52.81(Kumasi) & 16-Jan-03 & 0.9874 & \\
\hline & & & & $0.632-0.698$ & 1156.5 & & & & \\
\hline & & & & $0.757-0.853$ & 1156.9 & & & & \\
\hline
\end{tabular}

\subsubsection{ETM+ data to radiance}

The ETM +8 bit DNs were converted to radiances using the equation:

Radiance $\left(\mathrm{W} \mathrm{m}^{-2} \mathrm{sr}^{-1} \mu \mathrm{m}^{-1}\right)=$ gain $* \mathrm{DN}+$ offset ,

This can also be expressed as:

Radiance $\left(\mathrm{W} \mathrm{m}^{-2} \mathrm{sr}^{-1} \mu \mathrm{m}^{-1}\right)=\frac{\text { LMAX-LMIN }}{\text { QCALMAX-QCALMIN }} *($ QCAL-QCALMIN $)+$ LMI , (1b) where QCALMIN $=1$, QCALMAX $=225$, QCAL is the digital number, LMIN and LMAX are the spectral radiances for each band at DNs 1 and 255 (i.e. QCALMIN, QCALMAX), respectively. The LMAX and LMIN values (W/m2 Sr $\mu \mathrm{m}$ ) for the March 18, 2001, ETM+ image are: $\operatorname{LMAX}_{\text {band1 }}=191.600 ; \mathrm{LMIN}_{\text {band } 1}=-6.200 ; \mathrm{LMAX}_{\text {band2 }}=196.500 ; \mathrm{LMIN}_{\text {band2 }}=$ 6.400; $\operatorname{LMAX}_{\text {band3 }}=152.900 ; \mathrm{LMIN}_{\text {band3 }}=-5.000 ; \mathrm{LMAX}_{\text {band4 }}=241.100 ; \mathrm{LMIN}_{\text {band4 }}=-$ 5.100; $\operatorname{LMAX}_{\text {band5 }}=31.060 ; \mathrm{LMIN}_{\text {band5 }}=-1.000 ; \mathrm{LMAX}_{\text {band61 }}=17.040 ; \mathrm{LMIN}_{\text {band6 } 1}=$ $0.000 ; \operatorname{LMAX}_{\text {band62 }}=12.650 ; \operatorname{LMIN}_{\text {band62 }}=3.200 ; \operatorname{LMAX}_{\text {band } 7}=10.800 ; \operatorname{LMIN}_{\text {band } 7}=-$ $0.350 ; \operatorname{LMAX}_{\text {band8 }}=243.100 ; \operatorname{LMIN}_{\text {band } 8}=-4.700$.

\subsubsection{IKONOS data to radiance}

The 11-bit IKONOS DNs were converted to radiance $\left(\mathrm{m} \mathrm{W} \mathrm{cm}^{-2} \mathrm{sr}^{-1}\right)$ using the equation

$$
\mathrm{L}_{\mathrm{ij}}=\mathrm{DN}_{\mathrm{ij}}{ }^{*}\left[\mathrm{CalCoef}_{\mathrm{j}}\right]^{-1} \text {, }
$$

where $\mathrm{L}_{\mathrm{ij}}$ and $\mathrm{DN}_{\mathrm{ij}}$ are the in-band radiance at sensor aperture $\left(\mathrm{mW} \mathrm{cm}-\mathrm{cr}^{-1}\right)$ and image product digital value of the $\mathrm{i}^{\text {th }}$ pixel in the $\mathrm{j}^{\text {th }}$ band, respectively, and CalCoef $f_{\mathrm{j}}$ is the in-band radiance calibration coefficient ( $\mathrm{DN} \mathrm{cm}{ }^{2 *} \mathrm{sr} \mathrm{m}^{-1} \mathrm{~W}^{-1}$ ). Since the IKONOS image used in this study was acquired after February 22, 2001, the values of CalCoef $\mathrm{k}_{\mathrm{k}}$ used were 728 for band 1, 727 for band 2, 949 for band 3, and 843 for band 4 . 


\subsubsection{Radiance to reflectance}

A reduction in between-scene variability can be achieved through a normalization for solar irradiance by converting spectral radiance, as calculated above, to planetary reflectance or albedo $[13,16]$. This combined surface and atmospheric reflectance of the Earth is computed with the following formula:

$$
\rho_{\mathrm{p}}=\frac{\pi \mathrm{L}_{\lambda} \mathrm{d}^{2}}{\operatorname{ESUN}_{\lambda} \cos \theta_{\mathrm{S}}},
$$

where $\rho_{\mathrm{p}}$ is the at-satellite exo-atmospheric reflectance, $\mathrm{L}_{\lambda}$ is the radiance $\left(\mathrm{W} \mathrm{m}^{-2} \mathrm{sr}^{-1} \mu \mathrm{m}^{-1}\right)$, $\mathrm{d}$ is the earth to sun distance in astronomic units at the acquisition date [16], $\operatorname{ESUN}_{\lambda}$ is the mean solar exo-atmospheric irradiance $\left(\mathrm{W} \mathrm{m}^{-2} \mathrm{sr}^{-1} \mu \mathrm{m}^{-1}\right)$ or solar flux [17], and $\theta_{\mathrm{S}}$ is solar zenith angle in degrees (i.e., 90 degrees minus the sun elevation or sun angle when the scene was recorded as given in the image header file).

\subsubsection{Surface reflectance}

Atmospheric correction was performed using the improved dark object subtraction technique $[18,19]$ to derive surface reflectance from apparent reflectance.

\subsection{Secondary (ancillary) and remote sensing derived spatial data layers}

\subsubsection{Precipitation, ET, and slope from Secondary (or ancillary) data}

Secondary (or ancillary) sources of data were used to obtain spatial data layers for rainfall (http://www.osti.gov/energycitations/product) and evapotranspiration (http://www.iwmi.cgiar.org/WAtlas/atlas.htm). Slope data was derived using the Space Shuttle Radar Topographic Mission (SRTM) (http://srtm.csi.cgiar.org/) data. Slope (Fig. 3) is one of the important data layers with areas with low slopes ideally suited for rice cultivation since they require very little investment for land preparation, presence of rich fertile soils, and adequate water. Spatial distribution of slope over the detailed $(15 \mathrm{~km} \mathrm{X} 15 \mathrm{~km})$ study area is shown in Fig. 3 and Table 2 shows the area distribution among different slope classes. When the local slope values exceed $10^{\circ}$, the SRTM data is not very suitable [26]. However, only a negligible proportion of IV wetlands have such steep slopes, with overwhelming proportion of them $<4^{\circ}[4]$.

\subsubsection{Water availability in $I V$ wetlands from remote sensing and field plot data}

Availability of surface water resources within the study site was analyzed using drainage pattern characterized by distribution pattern of different stream orders. Typically, IV wetlands occur in 1 to $4^{\text {th }}$ order streams, beyond which they become flood plains. In general, lower order streams in Tamale and Kumasi showed seasonal flow of water while the higher order streams are characterized with a perennial flow. Nevertheless, the land suitability for rice cultivation depends on slope, soil, and water availability apart from other factors discussed in section 4.1 and its sub-sections. Table 3 summarizes the drainage characteristics of the study areas.

\subsubsection{Landuselland cover and vegetation derived from remote sensing}

Land use/ land cover (Fig. 5) pattern of the study site was analyzed and mapped using high 
resolution satellite imagery (Landsat/IKONOS data) acquired on two dates: January 16, 2003 and November 7, 1999 (Table 1) using methods and protocols described in [20,21]. The Table 4 summarizes the land extents under different land cover categories. The rainfed rice areas are either left fallow or have second crops (mainly vegetables) during summer. They are significantly wetter than the surroundings. As a result they are easily detected in summer imagery (e.g., Figure 5b) and delineated out as rainfed rice. The decision is separating this class is done using extensive field-plot data (used to re-affirm class labeling).
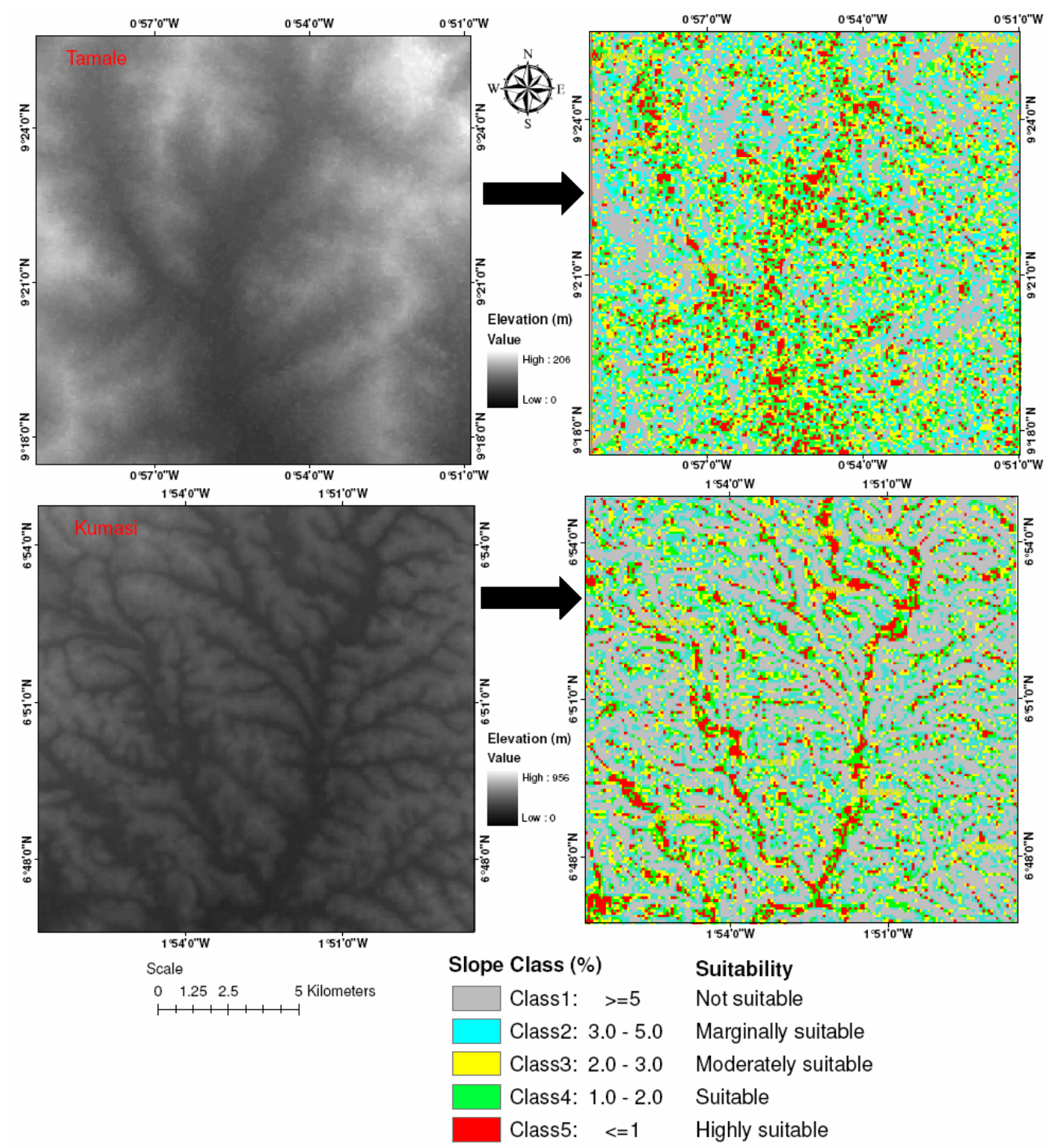

Fig. 3. Slope of the study areas derived using SRTM data. Top: Tamale, Bottom: Kumasi. Most to least suitable areas for rice cultivation based on slope alone as a parameter is illustrated. 
Table 2. Slope distribution in inland valley in detailed $(15 \mathrm{~km} \mathrm{x} 15 \mathrm{~km})$ study area. Lesser the slope, greater the suitability of land for IV wetland cultivation.

\begin{tabular}{cccccl}
\hline \multirow{2}{*}{ Slope Range } & \multicolumn{2}{c}{ Kumasi } & \multicolumn{2}{c}{ Tamale } & \multirow{2}{*}{ Suitability } \\
\cline { 2 - 5 } & $\begin{array}{c}\text { Area } \\
\text { (ha) }\end{array}$ & $\begin{array}{l}\text { \% } \\
\text { Area }\end{array}$ & $\begin{array}{l}\text { Area } \\
\text { (ha) }\end{array}$ & $\begin{array}{l}\text { \% } \\
\text { Area }\end{array}$ & \\
\hline$>=5$ & 9368 & 41.6 & 6569 & 29.2 & Not suitable \\
$3.0-5.0$ & 5891 & 26.2 & 4949 & 22.0 & Marginally suitable \\
$2.0-3.0$ & 2893 & 12.9 & 4633 & 20.6 & Moderately suitable \\
$1.0-2.0$ & 2494 & 11.1 & 4441 & 19.7 & Suitable \\
$<=1$ & 1854 & 8.2 & 1908 & 8.5 & Highly suitable \\
\hline
\end{tabular}
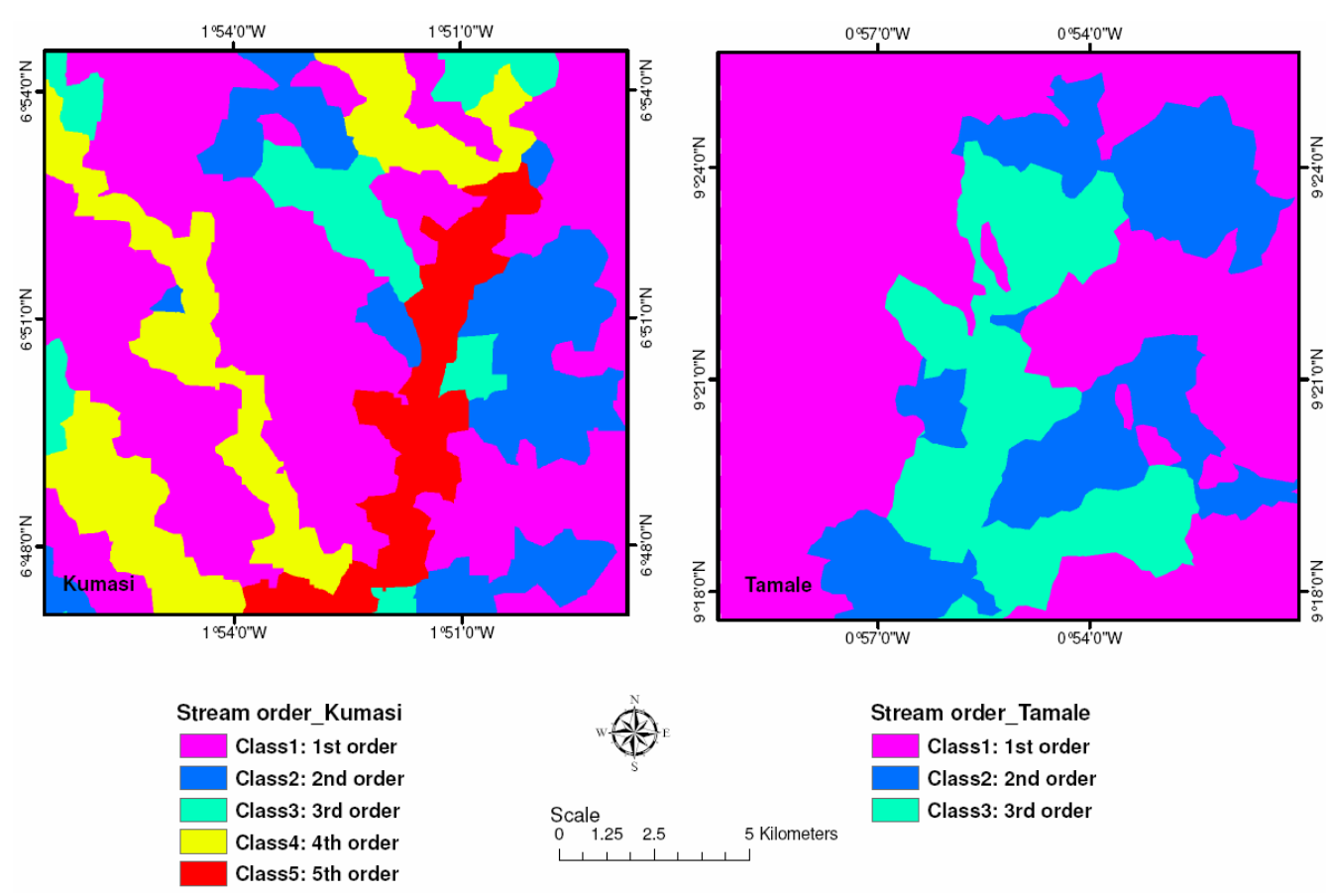

Fig. 4. Stream order of the study areas derived using SRTM data: (a) Kumasi (left), (b) Tamale (right).

Table 3. Drainage characteristics over the detailed study areas (Kumasi \& Tamale).

\begin{tabular}{ccccccc}
\hline \multirow{2}{*}{$\begin{array}{c}\text { Stream } \\
\text { order }\end{array}$} & $\begin{array}{c}\text { No. of } \\
\text { Streams }\end{array}$ & $\begin{array}{c}\text { Stream } \\
\text { Length } \\
\mathbf{( k m )}\end{array}$ & $\begin{array}{c}\text { Watershed } \\
\text { area (ha) }\end{array}$ & $\begin{array}{c}\text { No. of } \\
\text { Strea } \\
\text { ms }\end{array}$ & $\begin{array}{c}\text { Stream } \\
\text { Length } \\
(\mathbf{k m})\end{array}$ & $\begin{array}{c}\text { Watershed } \\
\text { area (ha) }\end{array}$ \\
\hline 1 & 78 & 128.25 & 11588.55 & 27 & 51.38 & 13785.02 \\
2 & 42 & 81 & 3366.88 & 7 & 30.1 & 4651.98 \\
3 & 16 & 74.25 & 1971.89 & 1 & 22.4 & 4063.00 \\
4 & 2 & 24.75 & 3652.51 & 0 & 0 & 0 \\
5 & 1 & 11.25 & 1921.17 & 0 & 0 & 0 \\
Total & 139 & 319.5 & 22500.00 & 35 & 103.88 & 22500.00 \\
\hline
\end{tabular}




\subsubsection{Soil characteristics from soil survey}

Detailed soil survey was conducted by the soil research institute (SRI) of Ghana by Dr.Buri. Soil characteristics of the study area were analyzed using results of the soil survey of 60 field plots for Kumasi and 45 field plots for Tamale (locations shown in Fig. 6), This reveals that the soils within the study sites are relatively deep with textures that vary from sandy loam through silt loam to loam. Table 5 summarizes the results of the soil parameters tested in the study.

\subsubsection{Socioeconomic data through field-surveys}

Socioeconomic survey was conducted in 15 villages for a total of 840 sample locations with each village having several samples (Fig. 7) and socioeconomic factors which includes farmer incentives (e.g., rice cultivation profitability), credit systems, land tenure systems, labour availability, rice cultivation experience, yield, post harvest technology, extension system, and water supply systems.

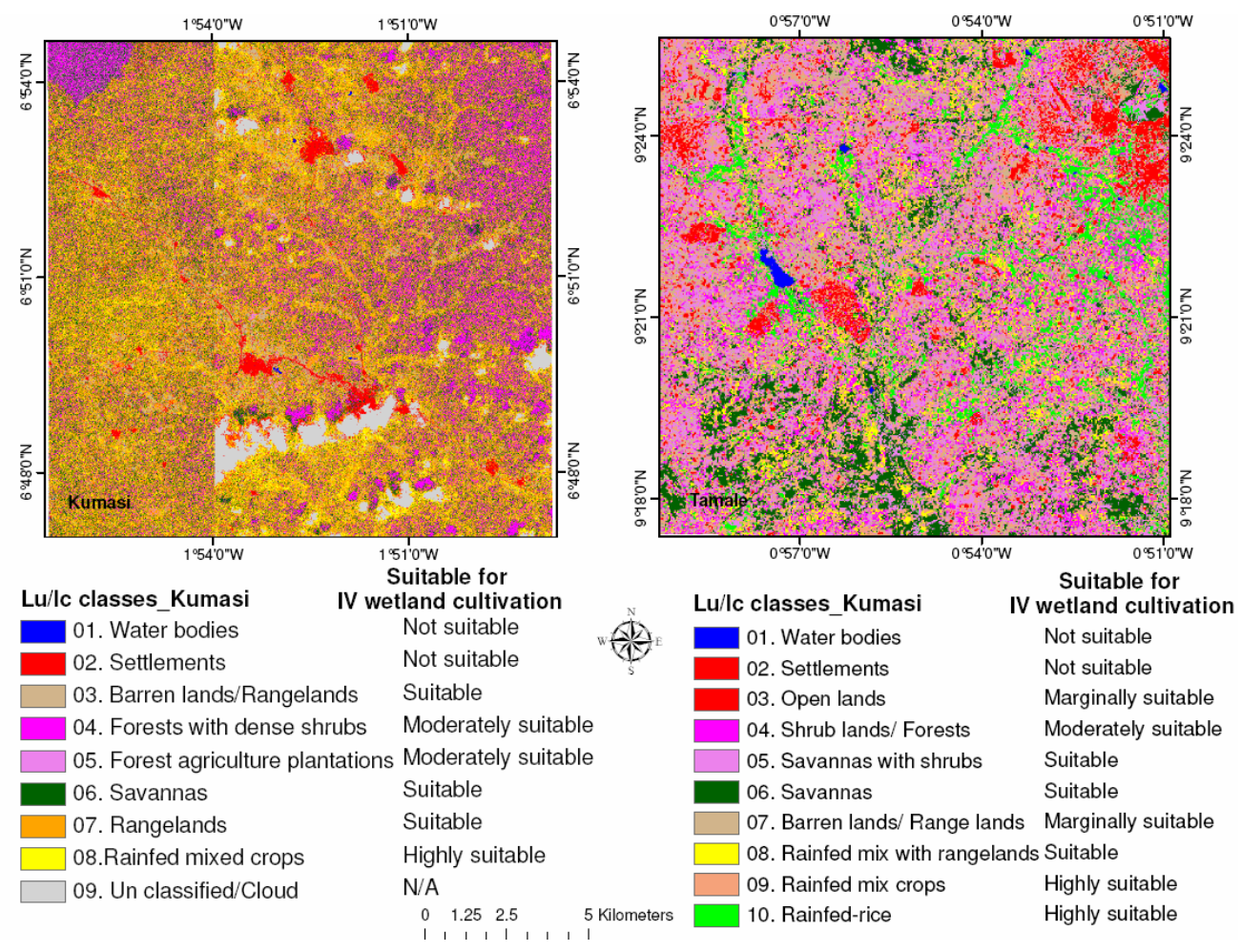

Fig. 5. Distribution of different land uselland cover (LULC) classes within the detailed (15 $\mathrm{km} \times 15$ km) study areas in: (a) Kumasi (left), and (b) Tamale (right), using IKONOS data. 
Table 4. Land uselland cover (LULC) categories and their land extents within the detailed (15 km x 15 $\mathrm{km})$ study areas using IKONOS data.

\begin{tabular}{|c|c|c|c|c|c|}
\hline \multicolumn{3}{|c|}{ Kumasi } & \multicolumn{3}{|c|}{ Tamale } \\
\hline Lulc class & $\begin{array}{c}\text { Area } \\
\text { (ha) }\end{array}$ & $\%$ Area & Lulc class & $\begin{array}{c}\text { Area } \\
\text { (ha) }\end{array}$ & $\%$ Area \\
\hline 01. Water bodies & 32 & 0.1 & 01. Water bodies & 62 & 0.3 \\
\hline 02. Settlements & 699 & 3.1 & 02. Settlements & 1457 & 6.5 \\
\hline 03. Barrenlands/Rangelands & 1511 & 6.7 & 03. Open lands & 132 & 0.6 \\
\hline 04 . Forest with dense shrubs & 4048 & 18.0 & 04. Shrublands/Forest & 3079 & 13.7 \\
\hline $\begin{array}{l}05 . \text { Forest/Agriculture } \\
\text { plantations }\end{array}$ & 41 & 0.2 & 05. Savannas with shrubs & 4343 & 19.3 \\
\hline 06. Savannas & 4156 & 18.5 & 06. Savannas & 2609 & 11.6 \\
\hline 07. Rangelnads & 8777 & 39.0 & 07. Barrenlands/Rangelands & 3104 & 13.8 \\
\hline rops & 2538 & 11.3 & $\begin{array}{l}\text { 08. Ranfed mix with } \\
\text { Rangelands }\end{array}$ & 1913 & 8.5 \\
\hline 09. Unclassified/Cloud & 697 & 3.1 & 09. Rainfed mix crops & 4266 & 19.0 \\
\hline \multirow[t]{2}{*}{ Total } & 22500 & 100.0 & 10. Rainfed-Rice & 1535 & 6.8 \\
\hline & & & Total & 22500 & 100 \\
\hline
\end{tabular}
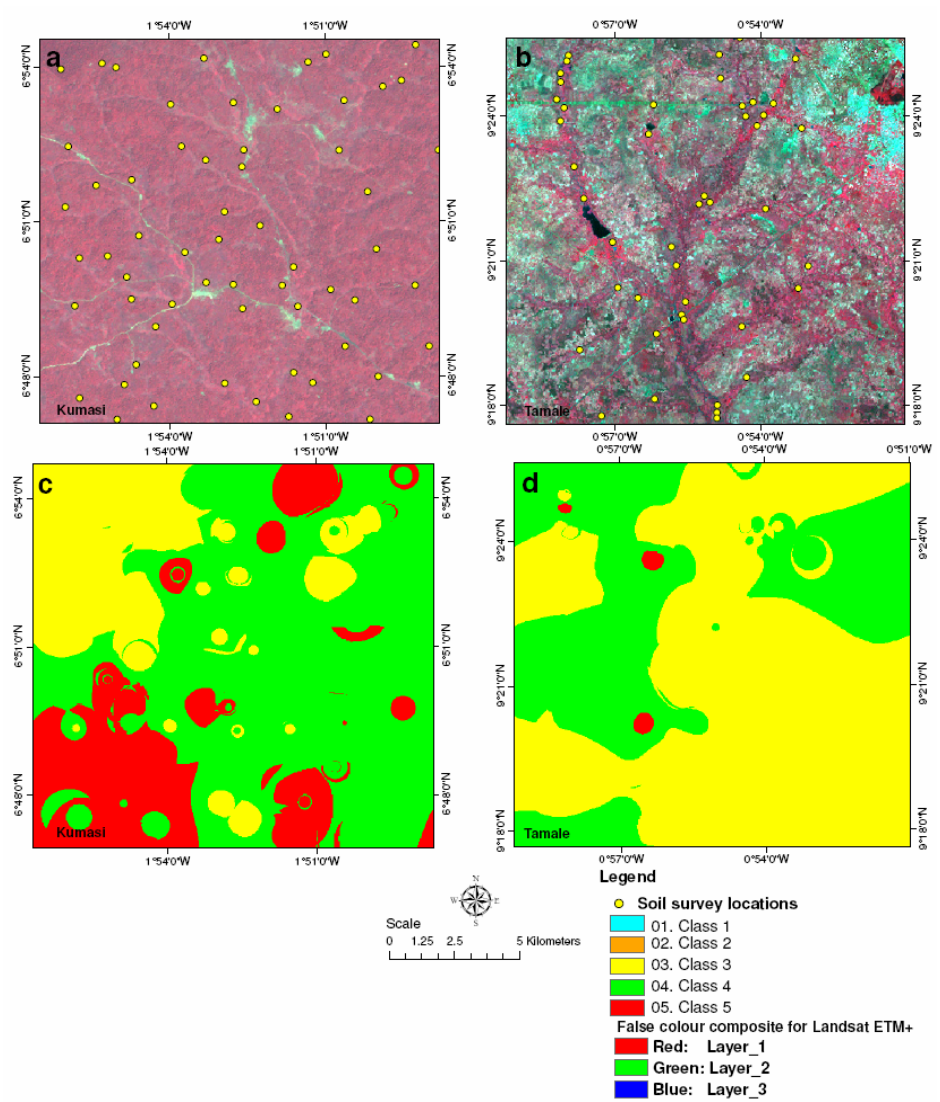

Fig. 6. Location of soil survey data points in the study areas of (a) Kumasi and (b) Tamale. The soil survey data points were spatially extrapolated, (c) and (d), to obtain soil map showing suitability for rice cultivation. 
Table 5. Summary of selected soil properties in Tamale and Kumasi in Ghana.

\begin{tabular}{|c|c|c|c|c|c|c|c|c|c|c|}
\hline \multirow[b]{2}{*}{ Parameter } & \multicolumn{5}{|c|}{ Kumasi } & \multicolumn{5}{|c|}{ Tamale } \\
\hline & \# sample & Mean & Minimu & Maximum & $\% \mathrm{CV}$ & \# sample & Mean & Minimu & Maximum & $\% \mathrm{CV}$ \\
\hline $\mathrm{pH}\left(\mathrm{H}_{2} \mathrm{O}\right)$ & 60 & 5.74 & 4.1 & 7.62 & 16 & 90 & 4.6 & 3.71 & 7.36 & 11.5 \\
\hline Or. $\mathrm{C}\left(\mathrm{gkg}^{-1}\right)$ & 60 & 12 & 3.6 & 36.5 & 48 & 90 & 6.14 & 0.6 & 19 & 49.5 \\
\hline Total N $\left(\mathrm{gkg}^{-1}\right.$ & 60 & 1.1 & 0.3 & 3.2 & 49 & 90 & 0.65 & 0.1 & 1.6 & 42.4 \\
\hline Av. $P\left(\mathrm{mgkg}^{-1}\right)$ & 60 & 4.94 & 0.1 & 28.5 & 94 & 90 & 1.49 & 0.3 & 5.35 & 61.2 \\
\hline Ex. K $\left\{\mathrm{cmol}(+) \mathrm{kg}^{-1}\right\}$ & 60 & 0.42 & 0.03 & 1.28 & 59 & 90 & 0.22 & 0.04 & 1.06 & 74.5 \\
\hline Ex. Ca $\left\{\mathrm{cmol}^{(+)} \mathrm{kg}^{-1}\right\}$ & 60 & 7.48 & 1.07 & 25.99 & 68 & 90 & 2.07 & 0.53 & 15 & 91 \\
\hline Ex. $\mathrm{Mg}\left\{\mathrm{cmol}(+) \mathrm{kg}^{-1}\right\}$ & 60 & 4.13 & 0.27 & 12.28 & 64 & 90 & 0.97 & 0.27 & 5.87 & 77.1 \\
\hline Ex. Na $\left\{\mathrm{cmol}(+) \mathrm{kg}^{-1}\right\}$ & 60 & 0.32 & 0.04 & 1.74 & 81 & 90 & 0.11 & 0.1 & 0.72 & 91.8 \\
\hline Ex. Ac. $\left\{\mathrm{cmol}(+) \mathrm{kg}^{-1}\right\}$ & 60 & 0.31 & 0.04 & 1.15 & 93 & 90 & 1.01 & 0.05 & 1.8 & 47.4 \\
\hline ECEC $\left\{\mathrm{cmol} \mathrm{(+)} \mathrm{kg}^{-1}\right\}$ & 60 & 12.7 & 2.45 & 34.63 & 59 & 90 & 4.4 & 2.28 & 21.7 & 58.4 \\
\hline Sand $\left(\mathrm{g} \mathrm{kg}^{-1}\right)$ & 60 & 371 & 91.6 & 771 & 37 & 90 & 326.6 & 51.4 & 590.8 & 37.2 \\
\hline Silt $\left(\mathrm{g} \mathrm{kg}^{-1}\right)$ & 60 & 502 & 187 & 770 & 22 & 90 & 607 & 347.6 & 810.5 & 17.6 \\
\hline Clay $\left(\mathrm{g} \mathrm{kg}^{-1}\right)$ & 60 & 127 & 41 & 301 & 44 & 90 & 66.3 & 40 & 241.4 & 58.9 \\
\hline Gravimetric moisture (\%) & 60 & 31 & 1 & 91 & 61 & 42 & 15.6 & 5.9 & 23.7 & 25.6 \\
\hline Volumetric moisture (\%) & 60 & 32 & 2 & 80 & 53 & 42 & 24.7 & 7.7 & 37.4 & 26.9 \\
\hline
\end{tabular}

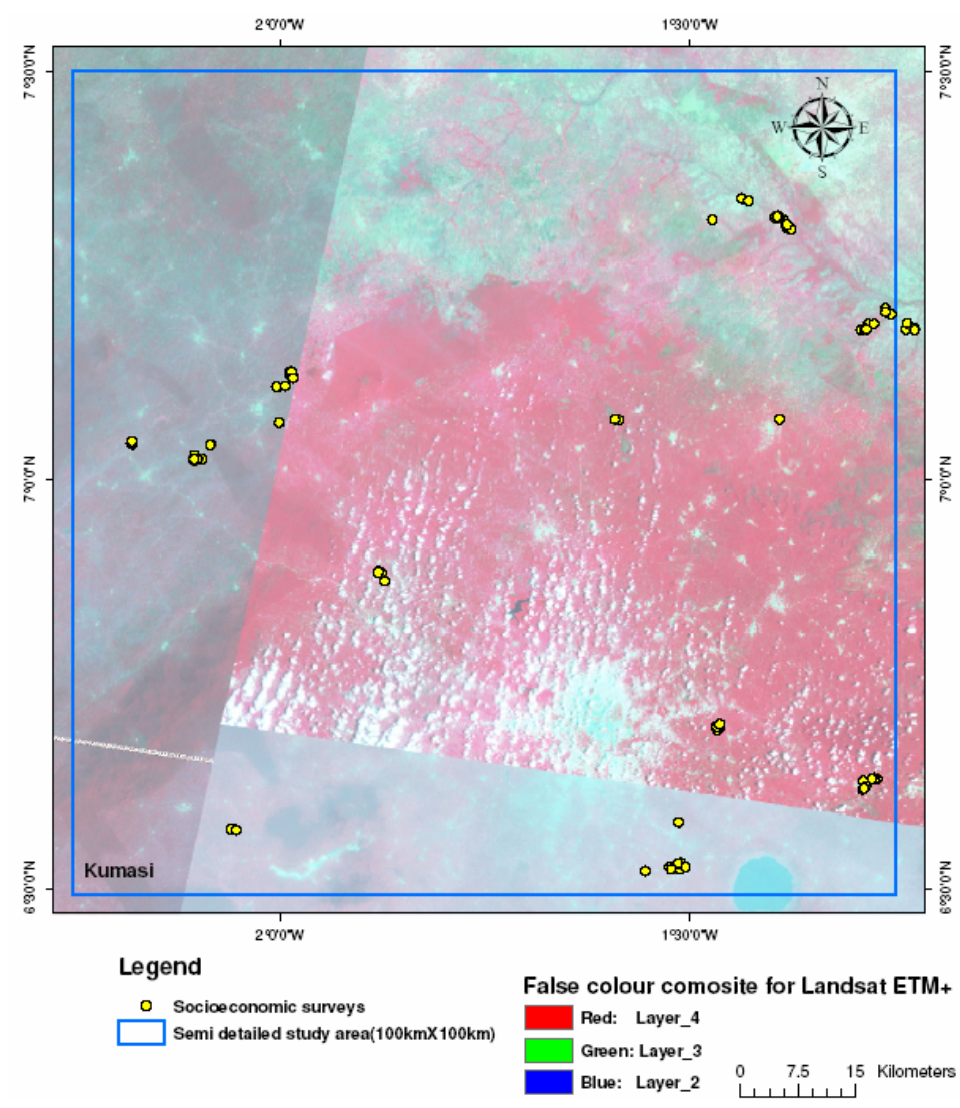

Fig. 7. Location of socioeconomic factors discussed in section 4.3.5. 


\subsubsection{Inland valley wetland delineation and characterization using remote sensing}

Remote sensing data was used to obtain information on IV wetland distribution (e.g., stream order, stream density, and valley bottom width), their characteristics (e.g., vegetation, land uselland cover). Remote sensing was also used to delineate road network, settlements, and locate markets. The methods for delineating IVs using imagery such as Landsat, IRS, Quickbird, and IKONOS are described in [4, 5, 22, and 23]. The semi-automated methods $[23,24]$ consisted of: (a) Enhancement of images through ratios to highlight wetlands from non-wetlands; (b) Display of enhanced images in red, green, blue (RGB) false color composites (FCCs) to highlight wetland boundaries; and (c) Digitizing the enhanced and displayed images and delineate wetlands from non-wetlands (Fig. 5). Once the images are enhanced and displayed at full pixel resolution, they are digitized directly off screen. The process of digitizing begins by selecting FCC RGBs that separate out wetlands from other land units. IVs occupied an area of 6240 ha (Fig. 8) from the detailed study area at Tamale (Fig. 8) and 7500 ha from the detailed study area at Kumasi (Fig. 8).
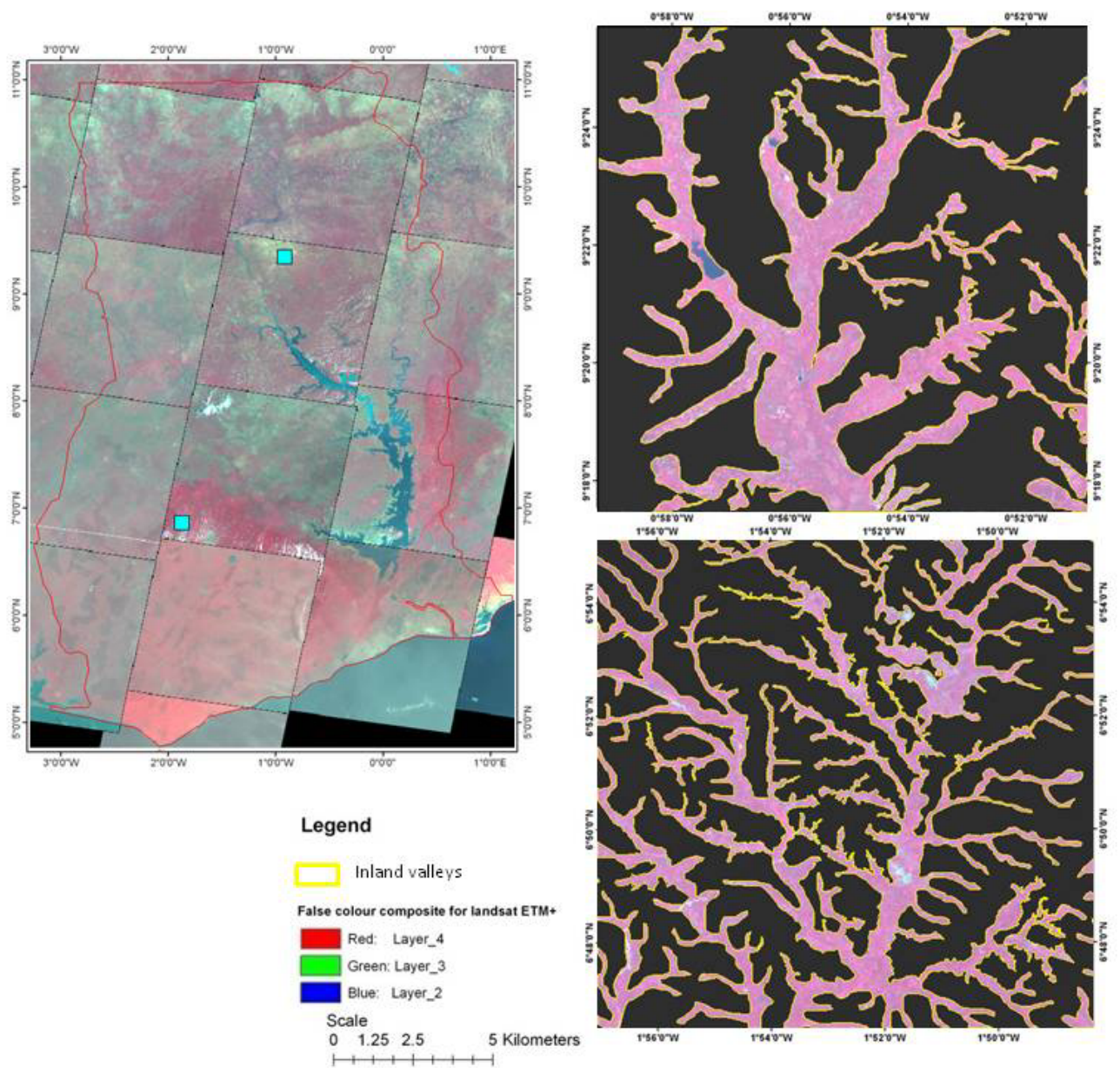

Fig. 8. Spatial distribution of IVs delineated using Landsat ETM+ data for: (a) Tamale (top), (b) Kumasi (bottom). 


\subsection{Providing weightages to spatial data layers}

In all, data were available for the 22 layers in Kumasi and 16 layers in Tamale (Table 6). These data layers were used in the spatial models (see section 4.4) to determine most suitable areas for rice cultivation. Two approaches were adopted in weighing layers. These were:

\subsubsection{Equal weights and variable scores}

In this approach, all spatial data layers had equal weights. Only the weights of classes within each layer were varied (Table 6).

\subsubsection{Variable weights and variable scores}

In this approach, all spatial data layers had variable weights based on importance of the layer as decided by experts (Table 7). There were 22 experts: 4 agronomists, 2 soil scientists, 3 economists, 4 agricultural extension officers, 2 socio-economists, 4 remote sensing specialists, and 3 water resources experts. In the process, slope was considered the most important layer (weight 2.95), followed by soil fertility, length of the growing period, and stream order. In contrast, the consideration of malaria had the least weightage. The weights of classes within each layers also varied (Table 7).

Table 6. Process of providing equal weights and variable scores for: (a) Kumasi (left), and (b) Tamale (right).

\begin{tabular}{|c|c|c|c|c|c|c|c|c|c|c|c|}
\hline \multirow[b]{2}{*}{ Factor } & \multicolumn{5}{|c|}{ Kumasi } & \multirow[b]{2}{*}{ Factor } & \multicolumn{5}{|c|}{ Tamale } \\
\hline & $\begin{array}{l}\text { Factor } \\
\text { weight }\end{array}$ & Score range & $\begin{array}{c}\text { Maximum } \\
\text { score }\end{array}$ & $\begin{array}{c}\text { Scores } \\
\text { given }\end{array}$ & Weighted score & & $\begin{array}{l}\text { Factor } \\
\text { weight }\end{array}$ & $\begin{array}{l}\text { Score } \\
\text { range }\end{array}$ & $\begin{array}{c}\text { Maximum } \\
\text { score }\end{array}$ & $\begin{array}{c}\text { Scores } \\
\text { given }\end{array}$ & $\begin{array}{c}\begin{array}{c}\text { Weighted } \\
\text { score }\end{array} \\
\end{array}$ \\
\hline 01-Annual-rainfall & 1 & $1-5$ & 3 & 3 & $(1 * 3)=3$ & 01-Annual-rainfall & 1 & $1-5$ & 3 & 3 & $(1 * 3)=3$ \\
\hline 02-PET & 1 & $1-5$ & 3 & 3,2 & $(1 * 3)=3$ & 02-PET & 1 & $1-5$ & 3 & 3,2 & $(1 * 3)=3$ \\
\hline 03-LPG & 1 & $1-5$ & 5 & 5 & $(1 * 5)=5$ & 03-LPG & 1 & $1-5$ & 3 & 3,2 & $(1 * 3)=3$ \\
\hline 04-specificdischarge & 1 & $1-5$ & 5 & $5,4,3,2,1$ & $(1 * 5)=5$ & 05-Stream order & 1 & $1-5$ & 3 & $3,2,1$ & $(1 * 3)=3$ \\
\hline 05-Stream order & 1 & $1-5$ & 5 & $5,4,3,2,1$ & $(1 * 5)=5$ & 07-Slope-percent & 1 & $1-5$ & 5 & $5,4,3,2,1$ & $(1 * 5)=5$ \\
\hline 07-Slope-percent & 1 & $1-5$ & 5 & $5,4,3,2,1$ & $(1 * 5)=5$ & 08-Lulc & 1 & $1-5$ & 5 & $5,4,3,2,1$ & $(1 * 5)=5$ \\
\hline 08-Lulc & 1 & $1-5$ & 5 & $5,3,2,1$ & $(1 * 5)=5$ & 09-Soils & 1 & $1-5$ & 3 & $3,2,1$ & $(1 * 3)=3$ \\
\hline 12-Experience in rice cult., & 1 & $1-5$ & 5 & 5,4 & $(1 * 5)=5$ & 10-Soil depth & 1 & $1-5$ & 5 & $5,4,3,2,1$ & $(1 * 5)=5$ \\
\hline 13-Agro., technology (yield) & 1 & $1-5$ & 4 & 4,3 & $(1 * 4)=4$ & 11- Soil fertility & 1 & $1-5$ & 5 & $5,4,3,2,1$ & $(1 * 5)=5$ \\
\hline 14-Watermangement tech., & 1 & $1-5$ & 2 & 2,1 & $(1 * 2)=2$ & 16a-Major settlement & 1 & $1-5$ & 5 & $5,4,3,2,1$ & $(1 * 5)=5$ \\
\hline 15-Postharvest tech., & 1 & $1-5$ & 5 & $5,4,3,2,1$ & $(1 * 5)=5$ & 16b-Minor settlement & 1 & $1-5$ & 5 & $5,4,3,2,1$ & $(1 * 5)=5$ \\
\hline 16a-Major settlement & 1 & $1-5$ & 5 & $5,4,3,2,1$ & $(1 * 5)=5$ & 17a-Major roads & 1 & $1-5$ & 5 & $5,4,3,2,1$ & $(1 * 5)=5$ \\
\hline 16b-Minor settlement & 1 & $1-5$ & 5 & $5,4,3,2,1$ & $(1 * 5)=5$ & 17b-Minor roads & 1 & $1-5$ & 5 & $5,4,3,2,1$ & $(1 * 5)=5$ \\
\hline 17a-Major roads & 1 & $1-5$ & 5 & $5,4,3,2,1$ & $(1 * 5)=5$ & 18a-Major markets & 1 & $1-5$ & 5 & $5,4,3,2,1$ & $(1 * 5)=5$ \\
\hline 17b-Minor roads & 1 & $1-5$ & 5 & $5,4,3$ & $(1 * 5)=5$ & $18 \mathrm{~b}-$ Minor markets & 1 & $1-5$ & 5 & $5,4,3,2,1$ & $(1 * 5)=5$ \\
\hline 18-Markets & 1 & $1-5$ & 5 & $5,4,3,2,1$ & $(1 * 5)=5$ & 25-Malaria & 1 & $1-5$ & 2 & 2,1 & $(1 * 2)=2$ \\
\hline 19-Land tenure & 1 & $1-5$ & 5 & $5,4,3,2,1$ & $(1 * 5)=5$ & & & & & & \\
\hline 20-Labour force & 1 & $1-5$ & 5 & $5,4,3,2,1$ & $(1 * 5)=5$ & & & & & & \\
\hline 21-Crdit system & 1 & $1-5$ & 3 & $3,2,1$ & $(1 * 3)=3$ & & & & & & \\
\hline 22-Extension system & 1 & $1-5$ & 5 & 5,4 & $(1 * 5)=5$ & & & & & & \\
\hline 24-Incentives_net benfit & 1 & $1-5$ & 3 & $3,4,5$ & $(1 * 3)=3$ & & & & & & \\
\hline 25-Malaria & 1 & $1-5$ & 3 & 3,4 & $(1 * 3)=3$ & & & & & & \\
\hline
\end{tabular}


Table 7. Process of providing variable weights and variable scores.

\begin{tabular}{|c|c|c|c|c|c|c|c|c|c|c|c|}
\hline \multirow[b]{2}{*}{ Factor } & \multicolumn{5}{|c|}{ Kumasi } & \multirow[b]{2}{*}{ Factor } & \multicolumn{5}{|c|}{ Tamale } \\
\hline & $\begin{array}{l}\text { Factor } \\
\text { weight }\end{array}$ & Score range & $\begin{array}{l}\text { Maximu } \\
\mathrm{m} \text { score }\end{array}$ & Scores given & Weighted score & & $\begin{array}{l}\text { Factor } \\
\text { weight }\end{array}$ & $\begin{array}{l}\text { Score } \\
\text { range }\end{array}$ & $\begin{array}{c}\text { Maximum } \\
\text { score }\end{array}$ & $\begin{array}{c}\text { Scores } \\
\text { given }\end{array}$ & Weighted score \\
\hline 01-Annual-rainfall & 1.89 & $1-5$ & 3 & 3 & $(1.89 * 3)=5.67$ & 01-Annual-rainfall & 1.89 & $1-5$ & 3 & 3, & $(1.89 * 3)=5.67$ \\
\hline 02-PET & 1.47 & $1-5$ & 3 & 3,2 & $(1.47 * 3)=4.41$ & 02-PET & 1.47 & $1-5$ & 3 & 3,2 & $(1.47 * 3)=4.41$ \\
\hline 03-LPG & 2.05 & $1-5$ & 5 & 5 & $(2.05 * 5)=10.25$ & 03-LPG & 2.05 & $1-5$ & 3 & 3,2 & $(2.05 * 3)=6.15$ \\
\hline 04-specificdischarge & 1.89 & $1-5$ & 5 & $5,4,3,2,1$ & $(1.89 * 5)=9.45$ & 05 -Stream order & 2.05 & $1-5$ & 3 & $3,2,1$ & $(2.05 * 3)=6.15$ \\
\hline 05 -Stream order & 2.05 & $1-5$ & 5 & $5,4,3,2,1$ & $(2.05 * 5)=10.25$ & 07-Slope-percent & 2.95 & $1-5$ & 5 & $5,4,3,2,1$ & $(2.95 * 5)=14.75$ \\
\hline 07-Slope-percent & 2.95 & $1-5$ & 5 & $5,4,3,2,1$ & $(2.95 * 5)=14.75$ & 08-Lulc & 1.37 & $1-5$ & 5 & $5,4,3,2,1$ & $(1.37 * 5)=6.85$ \\
\hline 08-Lulc & 1.37 & $1-5$ & 5 & $5,3,2,1$ & $(1.37 * 5)=6.85$ & 09-Soils & 1.53 & $1-5$ & 3 & $3,2,1$ & $(1.53 * 3)=4.59$ \\
\hline 12-Experience in rice cultivatiol & 1.42 & $1-5$ & 5 & 5,4 & $(1.42 * 5)=7.1$ & 10-Soil depth & 1.68 & $1-5$ & 5 & $5,4,3,2,1$ & $(1.68 * 5)=8.4$ \\
\hline 13-Agro., technology (yield) & 1.11 & $1-5$ & 4 & 4,3 & $(1.11 * 4)=4.44$ & 11- Soil fertility & 2.32 & $1-5$ & 5 & $5,4,3,2,1$ & $(2.32 * 5)=11.6$ \\
\hline 14-Watermangement tech,. & 1.68 & $1-5$ & 2 & 2,1 & $(1.68 * 2)=3.36$ & 16a-Major settlement & 1.5 & $1-5$ & 5 & $5,4,3,2,1$ & $(1.5 * 5)=7.5$ \\
\hline 15-Postharvest tech., & 1.05 & $1-5$ & 5 & $5,4,3,2,1$ & $(1.05 * 5)=5.25$ & 16b-Minor settlement & 1.5 & $1-5$ & 5 & $5,4,3,2,1$ & $(1.5 * 5)=7.5$ \\
\hline 16a-Major settlement & 1.5 & $1-5$ & 5 & $5,4,3,2,1$ & $(1.5 * 5)=7.5$ & 17a-Major roads & 1.7 & $1-5$ & 5 & $5,4,3,2,1$ & $(1.7 * 5)=8.5$ \\
\hline 16b-Minor settlement & 1.5 & $1-5$ & 5 & $5,4,3,2,1$ & $(1.5 * 5)=7.5$ & 17b-Minor roads & 1.7 & $1-5$ & 5 & $5,4,3,2,1$ & $(1.7 * 5)=8.5$ \\
\hline 17a-Major roads & 1.7 & $1-5$ & 5 & $5,4,3,2,1$ & $(1.7 * 5)=8.5$ & 18a-Major markets & 1.4 & $1-5$ & 5 & $5,4,3,2,1$ & $(1.4 * 5)=7$ \\
\hline 17b-Minor roads & 1.7 & $1-5$ & 5 & $5,4,3$ & $(1.7 * 5)=8.5$ & 18b-Minor markets & 1.4 & $1-5$ & 5 & $5,4,3,2,1$ & $(1.4 * 5)=7$ \\
\hline 18-Markets & 1.4 & $1-5$ & 5 & $5,4,3,2,1$ & $(1.4 * 5)=7$ & 25-Malaria & 0.41 & $1-5$ & 2 & 2,1 & $(0.41 * 2)=0.82$ \\
\hline 19-Land tenure & 1.74 & $1-5$ & 5 & $5,4,3,2,1$ & $(1.74 * 5)=8.7$ & & & & & & \\
\hline 20-Labour force & 1.53 & $1-5$ & 5 & $5,4,3,2,1$ & $(1.53 * 5)=7.65$ & & & & & & \\
\hline 21-Crdit system & 1.58 & $1-5$ & 3 & $3,2,1$ & $(1.58 * 3)=4.74$ & & & & & & \\
\hline 22-Extension system & 1.05 & $1-5$ & 5 & 5,4 & $(1.05 * 5)=5.25$ & & & & & & \\
\hline 24-Incentives_net benfit & 1.37 & $1-5$ & 3 & $3,4,5$ & $(1.37 * 3)=4.11$ & & & & & & \\
\hline 25-Malaria & 0.41 & $1-5$ & 3 & 3,4 & $(0.41 * 3)=1.23$ & & & & & & \\
\hline
\end{tabular}

In the variable weights and variable scores (Table 7), the classes within the layers are also given variable importance by the experts as per their knowledgelperception of how important the variable is for IV wetland rice cultivation. This lead to areas with least slope having highest total weightage (14.75), followed by soil and water layers. The differences in weightage between 2 approaches can be compared between Table 6 and 7 .

\subsection{Development of spatial model}

The first step in the spatial model development will be to have a clear and precise knowledge of how the spatial data layers and the classes within each spatial data layers are scored (Table 6 and 7). Once this knowledge is clear, the next step will be to build the spatial model (e.g., Fig. 9). This was done in the ERDAS spatial modeler as shown in Fig. 9. Two models were developed: one taking the weights and scores from Table 6 (approach 1) and another taking the weights and scores from Table 7 (Approach 2). The model is coded in ERDAS modeler as follows (Fig. 9):

Pixel score in model output $=$ weightage of layer $1 *$ weightages of classes within layer $1+$ weightage of layer $2 *$ weightages of classes within layer $2+\ldots \ldots \ldots \ldots . .+$ weightage of layer $\mathrm{n} *$ weightages of classes within layer $\mathrm{n}$.

In first approach weightages of layer 1 to $n$ will always be 1 whereas in approach 2 weightages of layer 1 to $\mathrm{n}$ will differ as per Table 7 . However, the weightages of classes within layer 1 to $\mathrm{n}$ will vary for both approaches. 


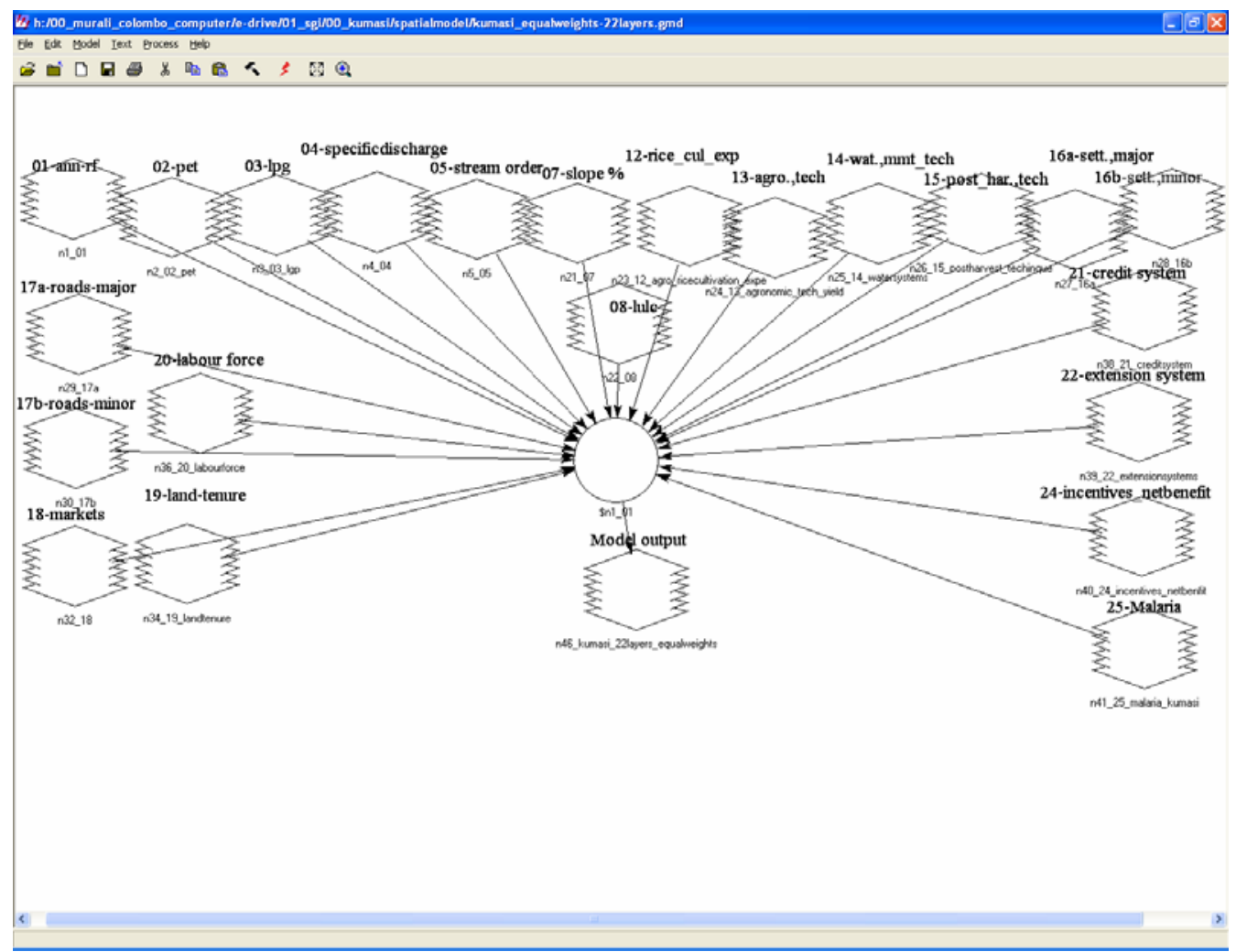

Fig. 9. Illustration of a typical spatial model built in ERDAS.

The model uses map algebra techniques [25] to arrive at the outputs. The map algebra techniques used in this model (Fig. 9). The detailed procedure of building and running the model are provided in Appendix 1.

\section{Results and discussions}

The spatial data layers (Fig. 2 and section 4.1 and 4.3) were weighted (section 4.4) and fed to the models (section 4.5) leading to generation of most suitable areas (Fig. 10) for inland valley (IV) wetland rice cultivation in the Tamale and Kumasi areas of Ghana. The models were first, run for entire datasets (uplands and lowlands). However, since our interest is in determining areas most suited for rice cultivation in the inland valley (IV) wetlands, we used the IV boundaries delineated in section 4.3.6 to mask out IV lowlands (Fig. 10) from uplands. The areas provided by the 2 approaches: (a) approach 1 (equal weights for layers and variable weights for classes), and (b) approach 2 (variables weights for the layers and variable weights for the classes) varied significantly in both study areas of Kumasi and Tamale. Often the spatial models were run using the approach 1 . This can be misleading as the importance of different spatial data layers can vary significantly as indicated by expert knowledge (Table 7) in this research. So, it is critical to provide greater importance to the results obtained from approach 2 .

As per approach 2 (variable weights for the layers and variable weights for the classes), Kumasi has 3\% (189 hectares or ha) of the total IV wetland area (6389 ha) as highly suitable and $36 \%$ area (2297 ha) as suitable (Table 8, Fig. 10). The results for Tamale were similar with $4 \%$ (236 ha) of the total IV wetland area (6240 ha) as highly suitable and $43 \%$ area ( $2710 \mathrm{ha}$ ) as suitable. Overall, $39-47 \%$ of the total IV wetland area is suitable or highly 
suitable for rice cultivation. These areas have low slopes $(<2 \%)$, rich soils in terms of soil depth, and fertility (soil fertility scores vary from 11 to 40 , high score is highly suitable), easy waterlmoisture availability, close to road-network, settlements, and markets. The spatial distributions of these suitable $\backslash$ most-suitable sites are shown in Fig. 10. The total area that is distributed across various spectrum of suitability (Fig. 10, Table 8) will depend on the number of spatial data layers and their weighting patterns. For example, Kumasi has 22 spatial data layers compared to 16 from Tamale. This may be one of the causes of the differences in total areas under most suitable and suitable categories for Tamale $(47 \%)$ versus Kumasi (39\%).
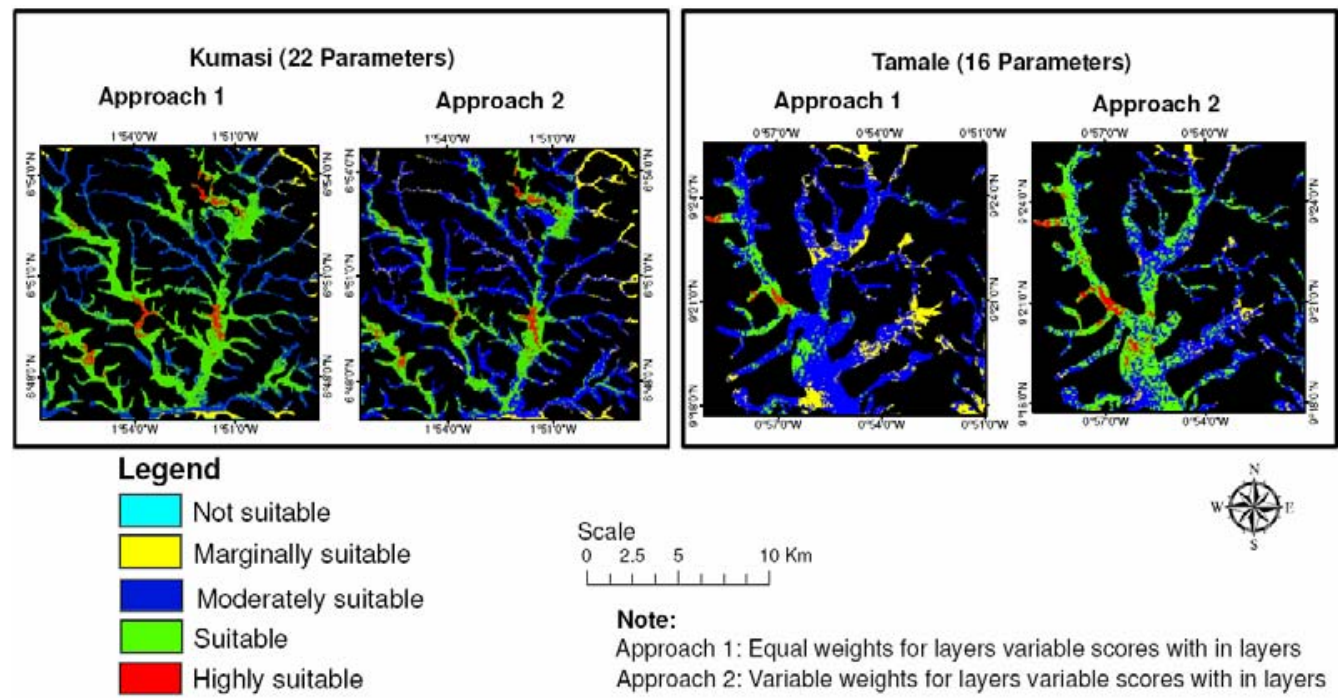

Approach 1: Equal weights for layers variable scores with in layers Approach 2: Variable weights for layers variable scores with in layers

Fig. 10. Most suitable sites for IVs rice cultivation in (a) Kumasi (left), and (b) Tamale (right). For each location the results and statistics are provided considering 16 variables and two approaches: (1) equal weight for layer, variable weight for classes within the layer; and (b) variable weight for layer, variable weight for classes within layer.

Table 8. Most suitable sites for IVs rice cultivation areas in (a) Kumasi (left), and (b) Tamale (right).

\begin{tabular}{llllllllll}
\hline & \multicolumn{3}{l}{ Kumasi } & & \multicolumn{2}{l}{ Tamale } \\
\cline { 2 - 9 } Suitability & \multicolumn{2}{l}{ Equal weights } & $\begin{array}{l}\text { Variable } \\
\text { weights }\end{array}$ & \multicolumn{2}{l}{ Equal weights } & \multicolumn{2}{l}{ Variable weights } \\
& $\begin{array}{l}\text { Area } \\
\text { (ha) }\end{array}$ & $\%$ & Area (ha) & $\%$ & Area (ha) & $\%$ & Area (ha) & $\%$ \\
\hline Not suitable & 8 & 0 & 8 & 0 & 0 & 0 & 0 & 0 \\
Marginally suitable & 310 & 5 & 663 & 10 & 1104 & 18 & 328 & 5 \\
Moderately suitable & 2187 & 34 & 3232 & 51 & 4313 & 69 & 2965 & 48 \\
Suitable & 3607 & 56 & 2297 & 36 & 762 & 12 & 2710 & 43 \\
Highly suitable & 276 & 4 & 189 & 3 & 62 & 1 & 236 & 4 \\
Total & 6389 & 100 & 6389 & 100 & 6240 & 100 & 6240 & 100 \\
\hline
\end{tabular}

\subsection{Accuracy assessment}

During the field visit, we collected data in Kumasi and Tamale on suitability for 5 distinct 
conditions: not suitable, marginally suitable, moderately suitable, suitable and highly suitable- to match with Figure 10 and Table 8 classes. These conditions were determined based on ground observations by field experts (groundtruth team that consisted of a local agronomist, water specialist, soil scientist, and a remote sensing expert). The precise locations of these areas were recorded using a GPS. Not suitable sites have either very poor soils, very steep slopes, or were inaccessible. Marginally suitable areas have limitations in soil and $l o r$ water apart from access and lor costly land preparation needs. Moderately suitable lands were prime for IV wetland cultivation in terms of soils and water, but required effort in access and land preparation. Suitable areas are similar to most suitable except for one or more limitations such as access or land preparation. Most suitable areas were prime in terms of soil and water as well as access and had least difficulty in preparing land for cultivation. These were also lands that are already in cultivation. In Tamale 45 points were gathered of which 8 were not suitable, 6 marginally suitable, 8 moderately suitable, 7 suitable, and 11 most suitable. In Kumasi, data was gathered from 44 locations- 11 not suitable, 5 marginally suitable, 7 moderately suitable, 14 suitable and 7 most suitable.

The above field truth points were overlaid on the outputs of approach 1 and 2 of Kumasi and Tamale (Figure 10). The best accuracies were obtained for approach 2 (variable weights for layers and variable weights for classes) - with overall accuracy of $84.4 \%$ for Kumasi and $87.5 \%$ for Tamale. The errors of omissions and commissions were $<23 \%$ for both areas. The confusion occurred mostly between close classes (e.g., marginal and moderate; suitable and most suitable).

\section{CONCLUSION}

This research espoused and illustrated spatial modeling approach for determining most suitable areas for inland valley (IV) wetland rice cultivation. The process involved: (a) identifying and developing harmonized spatial data layers of importance, (b) providing weightages to spatial data layers and classes within each data layers based on expert knowledge, (c) developing spatial models, and (d) running spatial models using spatial data and their weightages to arrive at areas most suitable areas for IV rice cultivation.

The study illustrated the successful application of the models in 2 distinct study areas of Ghana. The models provided the various levels of suitability, percentage areas most suited for IV wetland rice cultivation, and precise location of these areas.

The research showed that $20-28 \%$ of the total geographic area was inland valley wetlands. Of this, less than $15 \%$ of the area is currently cultivated. Of the $20-28 \%$ of IV wetland areas, $39-47 \%$ of the areas were considered suitable or most suitable for IV wetland cultivation. This mapping was performed with an overall accuracy of 84.4 to $87.5 \%$ with errors of omissions and commissions not exceeding $23 \%$ for the 4 suitability classes. In addition to these, IV wetlands have rich soils (depth and fertility) and have abundant water. These facts clearly imply that the IV wetlands will have a key role to play in the green and the blue revolution for Africa. The models precisely pin-point areas that have highest potential for IV wetland cultivation. The methods and models developed in this research can be applied across Africa to determine IV wetlands most suitable for rice cultivation in particular and development of agricultural lands in general.

\section{Acknowledgments}

This project was a sub-component of a larger project entitled "Research on Transferring Effective Irrigation and Water Resource Management Technique (TEIWRMT)" funded by the Ministry of Agriculture, Forestry and Fisheries (MAFF), Japan. The project was lead by Dr. Fujii Hideto. The first two authors would like to gratefully acknowledge the support of MAFF, Japan and Dr. Hideto. The paper was not internally reviewed by U.S. Geological 
Survey (USGS). So, it is no way endorsed by USGS. The opinions expressed in the paper are only those of the authors and not those of USGS.

\section{References}

[1] FAO, Irrigation in Africa in figures, AQUASTAT Survey-2005, FAO water reports 29 (2005).

[2] WARDA, Agriculture in Africa, West African Rice Development Authority (WARDA) annual report, Cononou, Republic of Benin (1986).

[3] WARDA, Agriculture in Africa, West African Rice Development Authority (WARDA) annual report, Cononou, Republic of Benin (1998).

[4] P. S. Thenkabail, C. Nolte, and J. G. Lyon, "Remote sensing and GIS modeling for selection of benchmark research area in the inland valley agroecosystems of West and Central Africa," Photogram. Eng. Rem. Sens. 66(6), 755-768 (2000).

[5] P. S. Thenkabail and C. Nolte, "Regional characterisation of inland valley agroecosystems in West and central Africa using high-resolution remotely sensed data," in GIS Applications for Water Resources and Watershed Management, J. G.. Lyon, Ed., pp. 77-99, Taylor and Francis, London and New York (2000).

[6] P. S. Thenkabail and C. Nolte, Mapping and Characterising Inland Valley Agroecosystems of West and Central Africa: A Methodology Integrating Remote Sensing, Global Positioning System, and Ground-Truth Data in a Geographic Information Systems Frame-work, RCMD Monograph No.16, 62 pp, International Institute of Tropical Agriculture, Ibadan, Nigeria (1995a).

[7] P. S. Thenkabail and C. Nolte, Regional characterisation of inland valley agroecosystems in Save, Bante, Bassila, and Parakou regions in south-central Republic of Benin through integration of remote sensing, global positioning system, and groundtruth data in a geographic information systems framework, Inland Valley Characterisation Report No.1, 60 pp, Resource and Crop Management Division, International Institute of Tropical Agriculture, Ibadan, Nigeria (1995b).

[8] P. S. Thenkabail and C. Nolte, Regional characterisation of inland valley agroecosystems in Gagnoa, Cote d'Ivoire through integration of remote sensing, global positioning systems, and ground-truth data in a geographic information systems framework, Inland Valley Characterisation Report No.2, 52pp, Resource and Crop Management Division, International Institute of Tropical Agriculture, Ibadan, Nigeria (1995c).

[9] P. S. Thenkabail and C. Nolte, Regional Characterisation of Inland Valley Agroecosystems in Sikasso, Mali and Bobo-Dioulasso, Burkina Faso through integration of Remote Sensing, Global Positioning Systems and Ground-Truth Data in a Geographic Information Systems Framework. Inland Valley Characterisation Report No.3, 46 pp, Resource and Crop Management Division, International Institute of Tropical Agriculture, Ibadan, Nigeria (1995d).

[10] P. S. Thenkabail and C. Nolte, Zooming in on backyard resources. Satellite imagery pinpoints the potential of inland valleys, Annual report of International Institute of Tropical Agriculture 1994, Ibadan, Nigeria (1995e).

[11] P. S. Thenkabail and C. Nolte, "Capabilities of Landsat-5 Thematic Mapper (TM) data in regional mapping and characterization of inland valley agroecosystems in 
West Africa," Int. J. Rem. Sens. 17(8), 1505-1538

(1996) [doi:10.1080/01431169608948721].

[12] F. Hideto, D. Busia, K. Wasantha, S. P. Thenkabail, and N. Regassa, "Features of river flow in Inland valleys in semi-deciduous forest zone in Ghana," (2009 in process).

[13] B. L. Markham and J. L. Barker, "Radiometric properties of U.S. processed Landsat MSS data," Rem. Sens. Environ. 22, 39-71 (1987) [doi:10.1016/00344257(87)90027-7].

[14] P. S. Thenkabail, E. A. Enclona, M. S. Ashton, C. Legg, and M. J. De Dieu, "Hyperion, IKONOS, ALI, and ETM+ sensors in the study of African rainforests," Rem. Sens. Environ. 90, 23-43 (2004) [doi:10.1016/j.rse.2003.11.018].

[15] P. S.Thenkabail, J. Hall, T. Lin, M. S. Ashton, D. Harris, and E. A. Enclona, "Detecting floristic structure and pattern across topographic and moisture gradients in a mixed species Central African forest using IKONOS and Landsat-7 ETM+ images," Int. J. Appl. Earth Observat. Geoinform. 4, 255-270 (2003) [doi:10.1016/S0303-2434(03)00006-0].

[16] B. L. Markham and J.L. Barker, Eds., "Special issue on Landsat image data quality assessment," Photogram. Eng. Rem. Sens. 51, 1245-1493 (1985).

[17] H. Neckel and D. Labs, "The solar radiation between 3300 and 12500 A," Solar Phys. 90, 205-258 (1984) [doi:10.1007/BF00173953].

[18] P. S. Chavez, Jr., "Image-based atmospheric corrections--revisited and improved," Photogram. Eng. Rem. Sens. 62(9), 1025-1036 (1996).

[19] P. S. Chavez, Jr., "An improved dark-object subtraction technique for atmospheric scattering correction of multispectral data," Rem. Sens. Environ. 24, 459-479 (1998) [doi:10.1016/0034-4257(88)90019-3].

[20] P. S. Thenkabail, C. M. Biradar, P. Noojipady, V. Dheeravath, Y. J. Li, M. Velpuri, M.Gumma, G.. P. O. Reddy, H. Turral, X. L. Cai, J. Vithanage, M. Schull, and R. Dutta, "Global Irrigated Area Map (GIAM) for the End of the Last Millennium Derived from Remote Sensing," Int. J. Rem. Sens. (2009 in press).

[21] C. M. Biradar, P. S. Thenkabail, P. Noojipady, L. Yuanjie, V. Dheeravath, M. Velpuri, H. Turral, M. K. Gumma, O. G. P. Reddy, X. L. Cai, X. Xiao, M. A. Schull, R. D. Alankara, S. Gunasinghe, and S. Mohideen, "A global map of rainfed cropland areas (GMRCA) at the end of last millennium using remote sensing," Int. J. Appl. Earth Observat. Geoinform. 11, 114-129 (2009) [doi:10.1016/j.jag.2008.11.002].

[22] M. A. Islam, P. S. Thenkabail, R. W. Kulawardhana, R. Alankara, S. Gunasinghe, C. Edussriya, and A. Gunawardana, 'Semi-automated methods for mapping wetlands using Landsat ETM+ and SRTM data," Int. J. Rem. Sens. 29(24),70777106 (2008) [doi:10.1080/01431160802235878].

[23] R. W. Kulawardhana, P. S. Thenkabail, J. Vithanage, C. Biradar, M. A. Islam, S. Gunasinghe, and R. Alankara, "Evaluation of the wetland mapping methods using Landsat ETM+ and SRTM data," J. Spatial Hydrol. 7(2), 62-966 (2007).

[24] P. S. Thenkabail, C. M. Biradar, H. Turral, P. Noojipady, Y. J. Li, J. Vithanage, V. Dheeravath, M. Velpuri, M. Schull, X. L. Cai, and R. Dutta, "An irrigated area map of the world (1999) derived from remote sensing," Research Report \# 105, International Water Management Institute, 74 pp., Colombo, Sri Lanka (2006). 
[25] Leica, Earth Resources Data Analysis System (ERDAS Imagine8.x), Leica Geosystems A.G. Heinrich-Wild-Strasse, CH-9435 Heerbrugg, Switzerland (2007).

[26] Y. Gorokhovic and A. Voustianiouk, "Accuracy assessment of the processed SRTMbased elevation data by CGIAR using field data from USA and Thailand and its relation to the terrain characteristics," Rem. Sens. Environ. 104(4), 409-415 (2006) [doi:10.1016/j.rse.2006.05.012].

Muralikrishna Gumma is special project scientist at International Water Management Institute. He is the author of more than 20 peer-reviewed scientific papers and book chapters of two books. His current research interests include global land remote sensing; Identify the best sites in inland valleys wetlands rice cultivation in Africa, land use and land cover change, cropping intensity, climate change and ecology of infectious diseases.

Prasad S. Thenkabail is a research geographer at the U.S. Geological Survey, Flagstaff, Arizona, USA. Prior to this he was a principal researcher and head of remote sensing at the International Water Management (IWMI). Prasad has $23+$ years experience working as a well recognized International expert in Remote Sensing and Geographic Information Systems (RS/GIS) and its applications to natural resources management, sustainable development, and environmental studies. He lead the global irrigated area mapping (GIAM) and water productivity mapping (WPM) projects at IWMI. Prasad has worked in over 25 Countries in Africa, Asia, Middle-East, and North America. He has $60+$ publications in major International journals. He is currently on the Landsat Science Team, editorial board of Remote Sensing of Environment (RSE), and one of the Associate Editor-in-Chief of Journal of Spatial Hydrology (JoSH)

Hideto Fujii is principal researcher at International Water Management Institute. He has 30 years of research and engineering experiences on agricultural hydrology, water resources management and irrigation engineering and computer software development. Prior to this he worked as Head of the Laboratory of River and Coastal Engineering, National Research Institute of Agricultural Engineering (NRIAE former NIRE), Ministry of Agriculture, Forestry and Fisheries (MAFF), and carried out the evaluation of hydrologic impacts of agricultural and forest lands on the environment, which is aimed at clarifying the multifunctionalities of agricultural land, such as the flood mitigation function and the water resources fostering function. He worked from 2001 to 2003, as Senior Advisor of the Hydrology Mekong River Commission (MRC) and carried out the project "Consolidation of Hydrologic Data and Evaluation of Multi-Functional Hydrologic Roles of Tonle Sap Lake and its Vicinities". He has 30+ publications in major International journals.

Regassa Namara is senior Research Economist at the International Water Management Institute. Has a PhD from University of Goettingen, Germany, and started his research career with Ethiopian Institute of Agricultural Research in 1987. His expertise includes agricultural economics, microeconomics of agricultural water management, innovation adoption and diffusion research, research and development impact evaluations, and socio-economics of rural development. Currently, he serves as guest lecturer of economics and financial analysis at UNESCO-IHE Institute for Water Education. Has substantial field research experience in many African and Asian countries. 